\title{
Climatological Vertical Features of Hadley Circulation Depicted by the NCEP/NCAR, ERA40, NCEP-DOE, JRA25, ERA-Interim, and CFSR Reanalyses
}

\author{
Juan Feng ${ }^{1,2}$, Jianlei Zhu ${ }^{3}$, and Fei $\mathrm{Li}^{4}$ \\ ${ }^{1}$ College of Global Change and Earth System Science, Beijing Normal University, Beijing, China \\ ${ }^{2}$ Joint Center for Global Change Studies, Beijing, China \\ ${ }^{3}$ State Key Laboratory of Numerical Modeling for Atmospheric Sciences and Geophysical Fluid Dynamics, \\ Institute of Atmospheric Physics, Chinese Academy of Sciences, Beijing, China \\ ${ }^{4}$ Department of Lower Atmosphere Observation Research, Institute of Atmospheric Physics, \\ Chinese Academy of Sciences, Beijing, China
}

\begin{abstract}
The climatological features of the pole-ward, equator-ward edges, and the width of the tropical Hadley Cell (HC) during the annual cycle in each hemisphere are studied based on six reanalyses datasets (i.e., NCEP/NCAR, NCEP-DOE, ERA40, JRA25, ERA-Interim, and CFSR). The result indicates that the amplitude of $\mathrm{HC}$ in the Northern Hemisphere $(\mathrm{NH})$ is much intense than that in the Southern Hemisphere (SH). And the amplitude of equator-ward edge is much larger than that of the pole-ward edges in both hemispheres. In addition, it is found that the ERA40, CFSR (for the pole-ward edge of $\mathrm{HC}$ in the $\mathrm{SH}$ ) and JRA25 (for the poleward edge of the $\mathrm{HC}$ in the $\mathrm{NH}$ ) show big inconsistency comparing with the other datasets in depicting the locations of pole-ward edges of $\mathrm{HC}$.
\end{abstract}

(Citation: Feng, J., J. Zhu, and F. Li, 2016: Climatological vertical features of Hadley circulation depicted by the NCEP/ NCAR, ERA40, NCEP-DOE, JRA25, ERA-Interim, and CFSR reanalyses. SOLA, 12, 237-241, doi:10.2151/sola.2016-047.)

\section{Introduction}

The tropical Hadley circulation (HC) is one of the most important atmospheric circulations, by definition, is the zonal mean meridional mass circulation in the atmosphere bounded roughly by $30^{\circ} \mathrm{S}$ and $30^{\circ} \mathrm{N}$. It is a thermally driven meridional circulation, with warmer tropical air rises due to the release of latent heat and colder air sinking in the subtropics in both hemispheres, generating an enclosed circulation in each hemisphere (Held and Hou 1980). It is characterized by equator-ward mass transport by the prevailing trade wind flow in the lower troposphere, and poleward mass transport in the upper troposphere. The HC is fundamentally important to the global climate system. It does not only transport heat from the tropics to the subtropics and to high latitudes through extratropical eddies but also transports momentum flux to the subtropics (Lindzen 1994; Hou 1998). Both heat and momentum transports have important influences on subtropical jet streams. Therefore, HC have important impacts on regional (e.g., Karnauskas and Ummenhofer 2014; Qin and Wang 2015) and global climate (e.g., Diaz and Bradley 2004; Zhou and Wang 2006).

In the recent few years, there have been growing interests in the changes of the HC. These studies were concerned with two key problems: one is the intensity of the $\mathrm{HC}$, and the other is its width (Hu and Zhou 2009). As to the strength of the HC, Chen et al. (2002) and Wielicki et al. (2002) suggested that the annual

Corresponding author: Jianlei Zhu, State Key Laboratory of Numerical Modeling for Atmospheric Sciences and Geophysical Fluid Dynamics (LASG), Institute of Atmospheric Physics (IAP), Chinese Academy of Sciences (CAS), Beijing 100029, China. E-mail: zhujl@mail.iap.ac.cn. (C)2016, the Meteorological Society of Japan. mean HC was intensified in the 1990s. Subsequently, the variations of $\mathrm{HC}$ in seasonal mean were discussed in many studies. Among these, the variations of HC in boreal winter (December to February, DJF) has been studied intensely, in which an obvious strengthening trend is observed. For example, Quan et al. (2004) reported that the HC has strengthened since the 1950s. Similar result was gotten by other studies despite different datasets or periods were focused ( $\mathrm{Hu}$ et al. 2005; Mitas and Clement 2005; $\mathrm{Ma}$ and Li 2007, 2008). Similar intensified trend is seen in boreal spring as reported in Kobayashi and Maeda (2006) and Feng et al. (2013). As to the boreal summer (June to August, JJA), it is found that the HC shows minor changes (e.g., Quan et al. 2004; Tanaka et al. 2004; Mitas and Clement 2006). As to the width of the HC, results from several recent studies suggested that the $\mathrm{HC}$ has poleward expansion since 1979 (e.g., Fu et al. 2006; $\mathrm{Hu}$ and $\mathrm{Fu}$ 2007; Seidal and Randel 2007), with a value within $1.21^{\circ}-5^{\circ}$ in different seasons based on different datasets (Hudson et al. 2006; Lu et al. 2007; Johanson and Fu 2009).

Besides, the long term variability of the $\mathrm{HC}$ is explored, and it is found that the long term variability of seasonal $\mathrm{HC}$ is dominated by an equatorially asymmetric mode in the four seasons (i.e., winter, spring, summer and autumn; Ma and Li 2008; Feng et al. 2011; Feng et al. 2013; Guo et al. 2016). And it is reported that the equatorially asymmetric mode is due to the inhomogeneous warming in the tropics, which altering the meridional gradient of underlying thermal structure, contributing to the formation of the equatorially asymmetric mode (Feng et al. 2013; Feng and Li 2013). And the long term variations of HC in the CMIP5 models have also been examined. For example, Hu et al. (2013) discussed the CMIP5 simulations of the poleward expansion of the $\mathrm{HC}$, and reported that the simulated poleward expansion in CMIP5 is much weaker than in the observations. Feng et al. (2015) found that CMIP5 models are moderately successful in capturing the HC's climatological features, but not for the spatial and temporal variations of its long term variability.

However, it is found that most of the work regarding the width of $\mathrm{HC}$ were mainly paid attention to the single level (i.e., 500 $\mathrm{hPa}$ ) to depict the pole-ward expansion of the $\mathrm{HC}$, which neither express the vertical structure or the variations in the whole troposphere. From the result followed we see that the pole-edge of $\mathrm{HC}$ in the Northern Hemisphere $(\mathrm{NH})$ within the troposphere could vary $\sim 5^{\circ}$ latitude, indicating an obvious vertical structure. On the other hand, the average between 600 and $400 \mathrm{hPa}$ is used to depict the edges of the $\mathrm{HC}$ whereas the $500 \mathrm{hPa}$ in Johanson and Fu (2009), indicated that using only one pressure level to yield the variation of $\mathrm{HC}$ is somewhat sensitive. Besides, it is reported that there is some disagreement with the exact pole-ward trend based on different datasets ( $\mathrm{Fu}$ et al. 2006; $\mathrm{Hu}$ and $\mathrm{Fu} 2007$ ), it becomes hard to distinguish which is more reasonable if we have not yielded a realization regarding the reliability of the datasets.

Therefore, it is necessary to further study the vertical structure of HC. In addition, considering there are large discrepancy among different datasets as noted (e.g., Pawson and Fiorino 1998; Zhao and Li 2006; Feng et al. 2013), six reanalysis datasets are 
employed to present more reliable result and give a direct comparison, which could provide a comprehensive realization for the capability of the commonly used reanalyses. Here, both the poleward and equator-ward edges of $\mathrm{HC}$, as well as the $\mathrm{HC}$ width are discussed, with an eye on their vertical distribution. The rest of this manuscript is divided as follows: the datasets and method are described in Section 2. The climatological vertical features of HC are presented in Section 3, with a brief conclusions and discussions in Section 4.

\section{Datasets and method}

\subsection{Observational datasets}

The six reanalysis datasets used in this study are from the National Centers for Environmental Prediction/National Center for Atmospheric Research (NCEP/NCAR) from the late 1940s to present (Kalnay et al. 1996), the National Centers for Environmental Prediction-Department of Energy (NCEP-DOE) Atmospheric Model Intercomparison Project (AMIP-2) reanalysis covering 1979-present (Kanamitsu et al. 2002), the 40-year European Centre for Medium-Range Weather Forecasts Reanalysis (ERA40) from 1957 to mid-2002 (Uppala et al. 2005), the Japanese 25-year reanalysis (JRA25) from 1979 to 2014 (Onogi et al. 2005), the ERA-Interim reanalysis from 1979 to present (ERA-Interim; Dee et al. 2011), and the NCEP Climate Forecast System Reanalysis from 1979 to 2010 (CFSR; Saha et al. 2010). All of them are on a $2.5^{\circ} \times 2.5^{\circ}$ horizontal resolution, and the whole troposphere is considered to show a vertical distribution of the HC's edges. Considering the period of the six reanalysis datasets, we select 1979-2000 as the common analysis period to explore the characteristics of monthly HC.

\subsection{Methodology}

The HC is characterized by the mass stream function (MSF) of the mean meridional circulation (MMC) obtained by vertically integrating meridional winds in the conventional way (Li 2001). Clockwise circulation (the northern cell) is defined as positive and anti-clockwise circulation (the southern cell) is defined as negative. The MSF is defined by:

$$
\psi=\int \frac{2 \pi R \cos \phi}{g}[\bar{v}] d p
$$

where $[\bar{v}]$ is the zonal mean meridional wind, $R$ is the mean radius of the earth, $\phi$ is the latitude, $g$ is gravity, $p$ is the pressure. The operators ' - ' and '[ ]' represent temporal and zonal average, respectively. The locations of pole-ward and equator-ward edges of $\mathrm{HC}$ are identified as the latitudes where MSF equals $0 \mathrm{~kg} \mathrm{~s}^{-1}$ in the troposphere, which are obtained using linear interpolation, then the width of the $\mathrm{HC}$ could be derived by the differences between the locations of the pole-ward and equator-ward edges.

\section{The climatological vertical features of edges and width of the $\mathrm{HC}$}

\subsection{Seasonal cycle of the equator-ward edge of $\mathrm{HC}$}

The climatological mean latitudes of the equator-ward edge of $\mathrm{HC}$ in the troposphere are shown in Fig. 1. We see that all the six reanalyses show that the equator-ward edge of $\mathrm{HC}$ exhibit strong seasonal variations, with the southernmost position (about $10^{\circ} \mathrm{S}$ ) during December-February, while locates in the northernmost positions (about $18^{\circ} \mathrm{N}$ ) during July-August, indicating the upward edge of $\mathrm{HC}$ shifts nearly $30^{\circ}$ latitudes during the seasonal march. From January to August, the equator-ward edge shifts northwardly, after then shifts to the south. In addition, the locations within the troposphere show small vertical structure, especially during the boreal winter half year (November to April).

\subsection{Seasonal cycle of the pole-ward edge of HC in the Northern Hemisphere}

Figure 2 shows the climatological mean locations of the poleward edge of the $\mathrm{HC}$ in the $\mathrm{NH}$. Unlike the equator-ward edge of $\mathrm{HC}$, there are big discrepancies among the six reanalyses. Note that the southernmost location is around $28^{\circ} \mathrm{N}$ in May in the NCEP-NCAR, NCEP-DOE, ERA40 and CFSR, whereas it is in March for the JRA25. Despite of this discrepancy, more consistent features are observed in the northernmost position of the poleward edge, around $40^{\circ} \mathrm{N}$ in August-September. This point infers the result from JRA25 shows large discrepancy from the other five
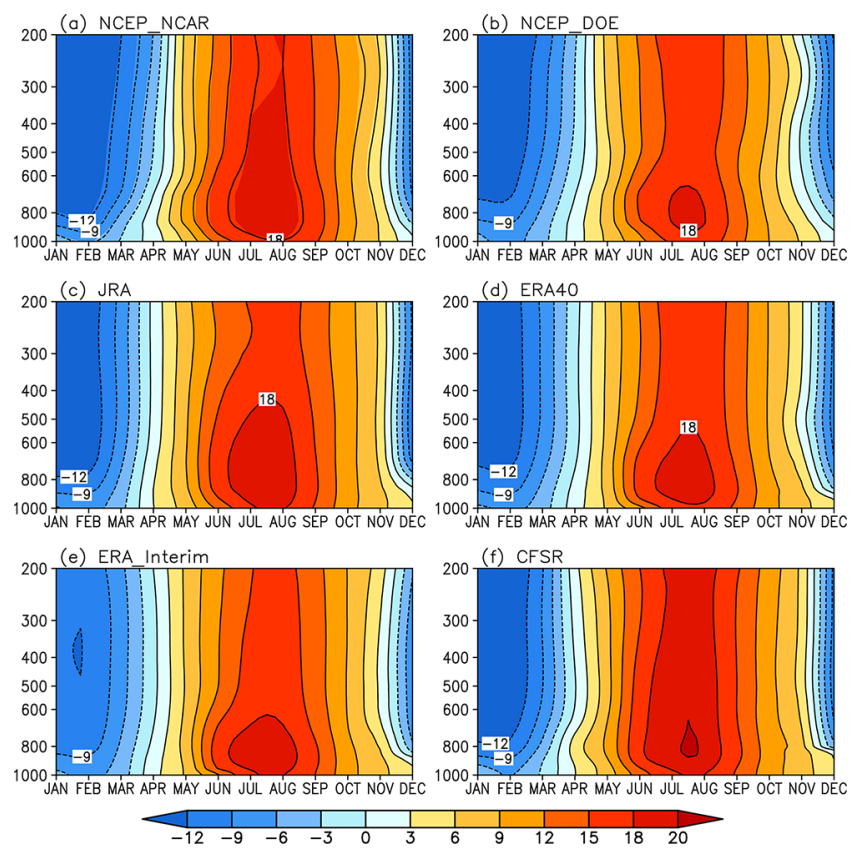

Fig. 1. Time-height distribution of the equator-ward edge locations of the Hadley Cell based on the (a) NCEP-NCAR, (b) NCEP-DOE, (c) JRA, (d) ERA40, (e) ERA-Interim, and (f) CFSR reanalyses, respectively. (Units: ${ }^{\circ}$ latitude).
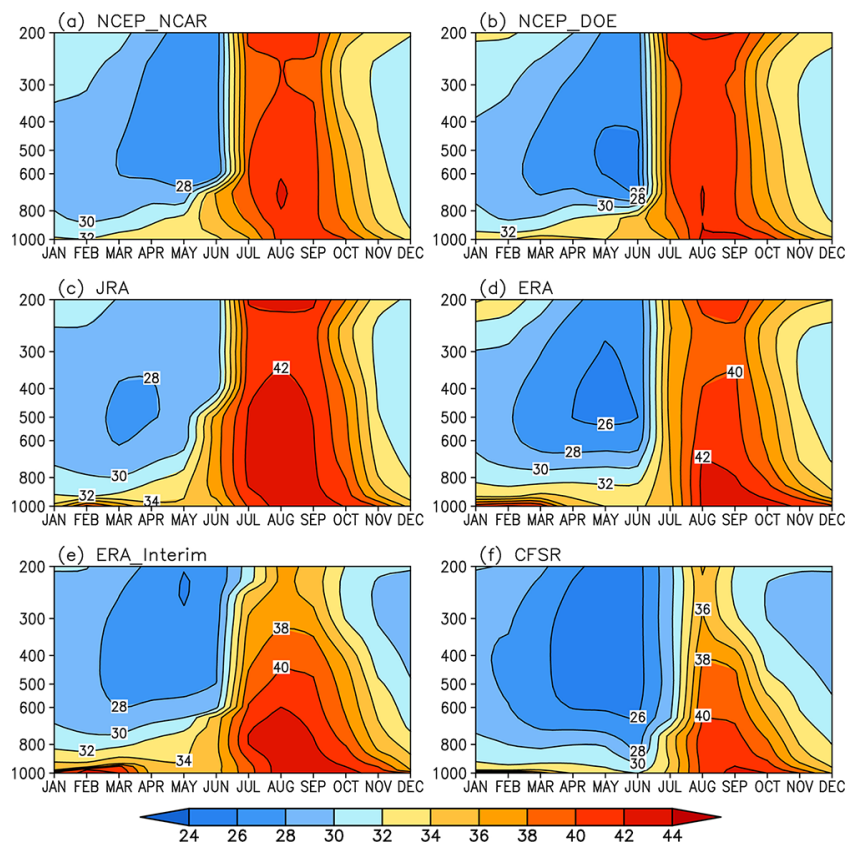

Fig. 2. As in Fig. 1, but for the time-height distribution of the pole-ward edge locations of the Hadley Cell in the Northern Hemisphere. 
reanalyses in depicting the location of $\mathrm{HC}$ pole-ward edge in the $\mathrm{NH}$. This may due to the fact that the terrain in the extra-tropical is more complexity comparing to the tropical regions. In addition, unlike the equator-ward edge of $\mathrm{HC}$, the pole-ward edge of $\mathrm{HC}$ in the NH shows large vertical structure, particularly for the period from January to May. Note that lower troposphere expand earlier than upper troposphere in all the reanalyses implying that $\mathrm{HC}$ is an underlying thermal driven circulation. The vertical difference of the location is mainly due to the difference between the lower and middle to upper levels, varying around $5^{\circ}$ latitudes.

To this point, the variation of $\mathrm{HC}$ width the $\mathrm{NH}$ is gotten as displayed in Fig. 3. We see that the HC reaches its widest extension during January-February, with an extent around $45^{\circ}$ latitudes, and being narrowest in June with an extent of $15^{\circ}$ latitudes. Moreover, from June to December, the extension of $\mathrm{HC}$ in the $\mathrm{NH}$ shifts about $20^{\circ}$ latitudes; however it varies nearly $30^{\circ}$ latitudes from January to June, indicating an asymmetric variation during the seasonal march.

\subsection{Seasonal cycle of the pole-ward edge of HC in the Southern Hemisphere}

The climatological mean latitudes of the pole-ward edge at different levels in the Southern Hemisphere (SH) are shown in Fig. 4. Most of the reanalyses (i.e., NCEP/NCAR, NCEP-DOE, JRA25, and ERA-Interim) show that the pole-ward edges of HC in the $\mathrm{SH}$ exhibit strong seasonal variations, with the southernmost position $\left(\sim 37^{\circ} \mathrm{S}\right)$ during February-March, while locates in the northernmost position $\left(\sim 28^{\circ} \mathrm{S}\right)$ during June-July, inferring that the position of $\mathrm{HC}$ pole-ward edge in the SH shifts nearly $10^{\circ}$ latitude during the annual cycle. From January to July, the pole-ward edge shifts northwardly, and southwardly after July. In addition, the asymmetric variation of the pole-ward during the seasonal cycle is observed from all the six reanalyses. From January to July, the shift of the pole-ward edge is much swifter than that after July, reflecting the asymmetry of the $\mathrm{HC}$ intensity (Oort and Yienger 1996). Besides the consistency of the four reanalyses, it is seen the northernmost position in ERA40 and CFSR is in September in the upper troposphere, which is later compared with the other reanalyses. Considering that the $\mathrm{HC}$ is mainly a thermal driven circulation, and it shifts along with the sun, largely implying the result here based on ERA40 and CFSR is not reasonable. Moreover, we see that the level of maximum latitude of the edge loca-
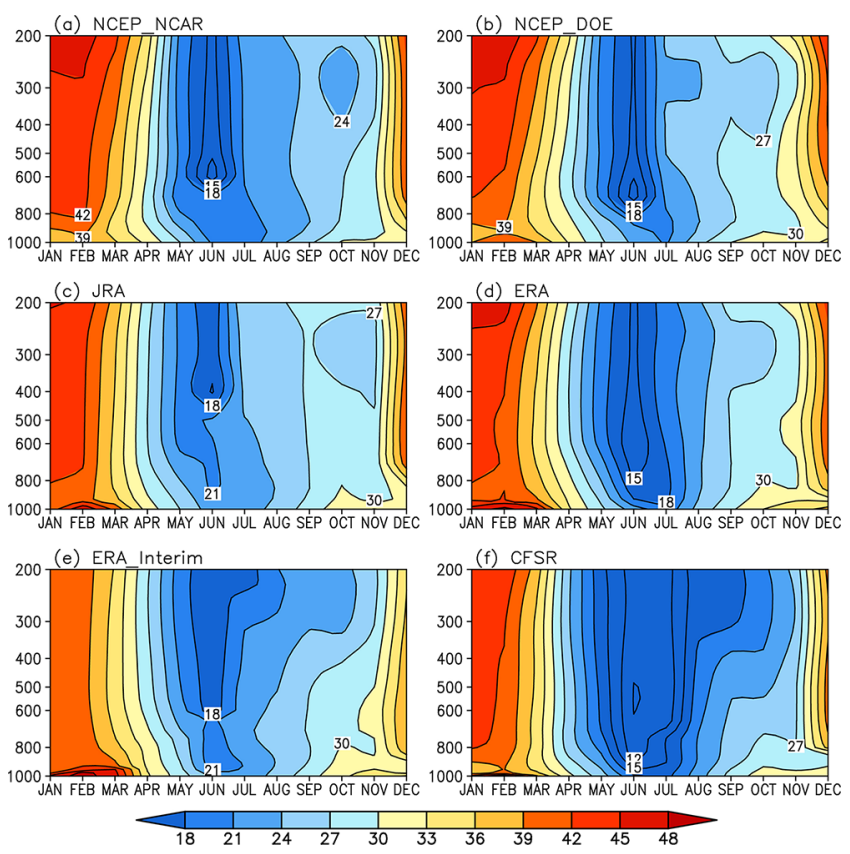

Fig. 3. As in Fig. 1, but for the time-height distribution of the width of the Hadley Cell in the Northern Hemisphere. tions in NCEP/NCAR and NCEP-DOE are in lower troposphere, but the it locates in the upper troposphere in other reanalyses. The possible cause for this inconsistency could not be explained by the underlying thermal distribution, and worthy other data to further establish.

Figure 5 displays the seasonal march of the $\mathrm{HC}$ width in the $\mathrm{SH}$, we see that the $\mathrm{HC}$ reaches the widest extent during JulyAugust which could reach $48^{\circ}$ latitudes, and being narrowest during December-January with an extension about $20^{\circ}$ latitudes. That is the amplitude of $\mathrm{HC}$ width varies nearly $30^{\circ}$ latitudes along with the seasonal march.

The result above indicates that the positions of $\mathrm{HC}$ edges, as well as its width represents strong seasonal variation. For a direct
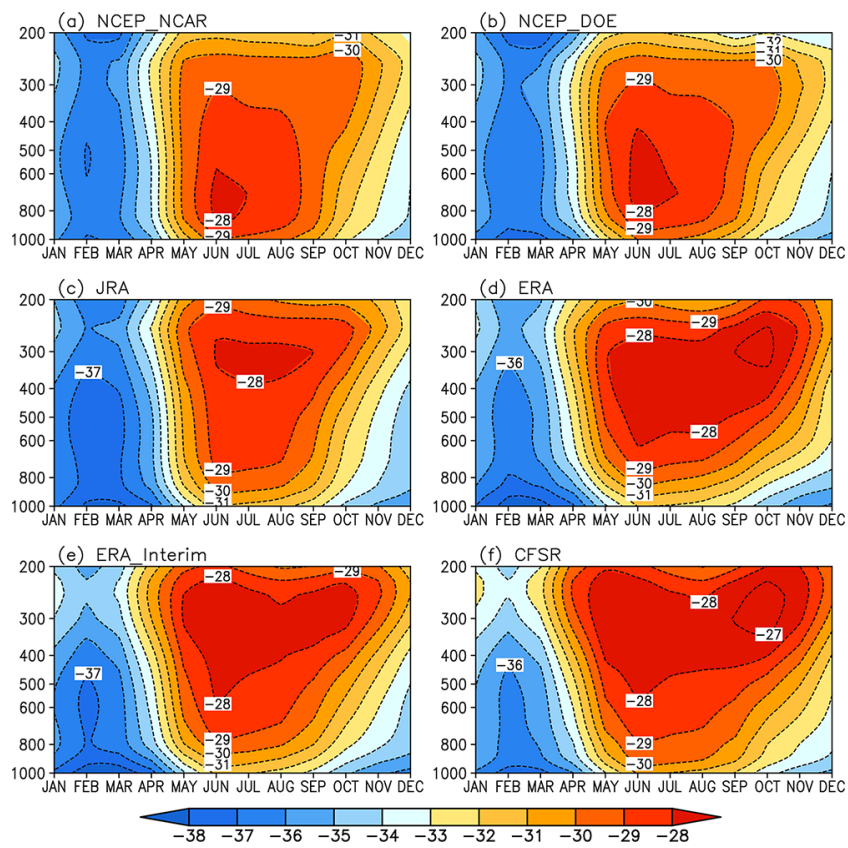

Fig. 4. As in Fig. 1, but for the time-height distribution of the pole-ward edge locations of the Hadley Cell in the Southern Hemisphere.
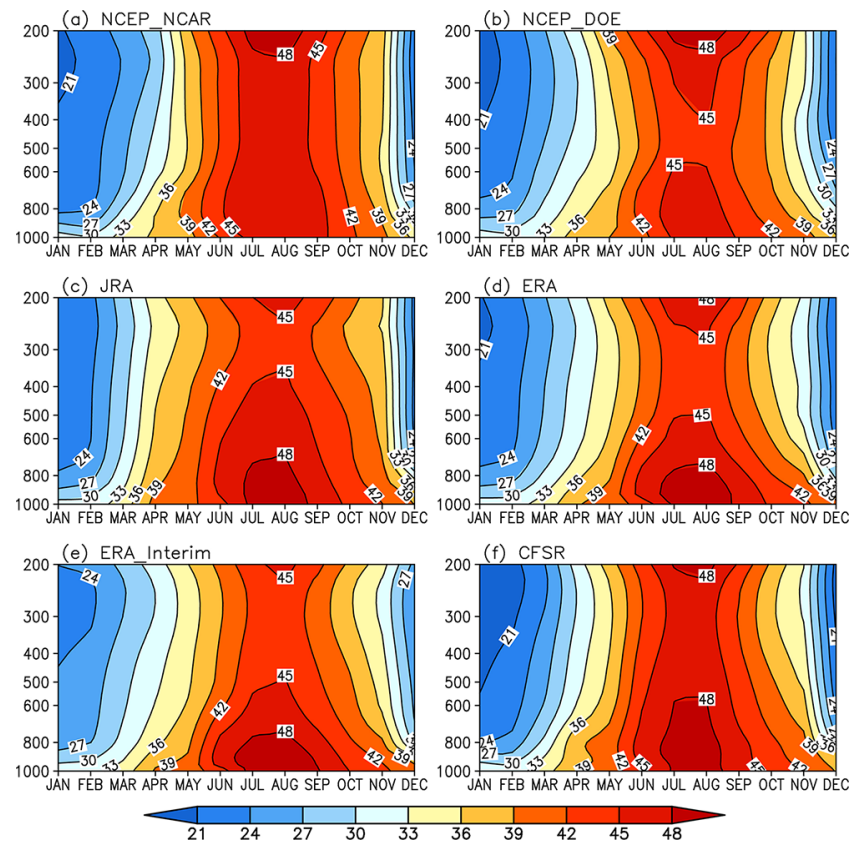

Fig. 5. As in Fig. 1, but for the time-height distribution of the width of the Hadley Cell in the Southern Hemisphere. 
Table 1. The statistical result of the equator-ward and pole-ward locations, and the width of $\mathrm{HC}$ in both the Northern Hemisphere (NH) and Southern Hemisphere (SH) during the seasonal march in the climatological mean during 1979-2000.

\begin{tabular}{|c|c|c|c|c|c|c|c|c|}
\hline & & \multicolumn{2}{|c|}{ Northernmost } & \multicolumn{2}{|c|}{ Southernmost } & \multirow{2}{*}{ Amplitude } & \multicolumn{2}{|c|}{ Width } \\
\hline & & Locations & Time & Locations & Time & & Max & Min \\
\hline \multirow{6}{*}{$\begin{array}{c}\mathrm{SH} \\
\text { (pole-ward) }\end{array}$} & NCEP1 & $27.70^{\circ} \mathrm{S}$ & Jun & $37.26^{\circ} \mathrm{S}$ & Mar & $9.56^{\circ}$ & $49.79^{\circ}$ (Aug) & $20.29^{\circ}(\operatorname{Jan})$ \\
\hline & NCEP2 & $27.51^{\circ} \mathrm{S}$ & Jun & $37.82^{\circ} \mathrm{S}$ & Mar & $10.31^{\circ}$ & $49.76^{\circ}$ (Aug) & $19.92^{\circ}$ (Jan) \\
\hline & ERA40 & $26.67^{\circ} \mathrm{S}$ & Oct & $38.48^{\circ} \mathrm{S}$ & $\mathrm{Feb}$ & $11.81^{\circ}$ & $49.55^{\circ}$ (Aug) & $20.33^{\circ}($ Jan $)$ \\
\hline & JRA25 & $27.85^{\circ} \mathrm{S}$ & Aug & $38.23^{\circ} \mathrm{S}$ & $\mathrm{Feb}$ & $10.38^{\circ}$ & $49.16^{\circ}$ (Aug) & $21.06^{\circ}$ (Jan) \\
\hline & ERA-Interim & $19.25^{\circ} \mathrm{S}$ & Aug & $39.67^{\circ} \mathrm{S}$ & Mar & $20.42^{\circ}$ & $50.46^{\circ}$ (Aug) & $22.54^{\circ}(\mathrm{Jan})$ \\
\hline & CFSR & $26.55^{\circ} \mathrm{S}$ & Oct & $40.71^{\circ} \mathrm{S}$ & Mar & $14.16^{\circ}$ & $51.70^{\circ}$ (Aug) & $18.07^{\circ}(\mathrm{Jan})$ \\
\hline \multirow{6}{*}{$\begin{array}{c}\mathrm{NH} \\
\text { (pole-ward) }\end{array}$} & NCEP1 & $42.33^{\circ} \mathrm{N}$ & Aug & $26.32^{\circ} \mathrm{N}$ & May & $16.01^{\circ}$ & $46.60^{\circ}(\mathrm{Feb})$ & $10.49^{\circ}$ (Jun) \\
\hline & NCEP2 & $42.10^{\circ} \mathrm{N}$ & Aug & $25.73^{\circ} \mathrm{N}$ & May & $16.37^{\circ}$ & $48.02^{\circ}(\mathrm{Jan})$ & $10.56^{\circ}$ (Jun) \\
\hline & ERA40 & $42.52^{\circ} \mathrm{N}$ & Aug & $25.67^{\circ} \mathrm{N}$ & May & $16.85^{\circ}$ & $47.57^{\circ}(\mathrm{Jan})$ & $12.27^{\circ}$ (Jun) \\
\hline & JRA25 & $43.54^{\circ} \mathrm{N}$ & Aug & $27.63^{\circ} \mathrm{N}$ & Mar & $15.91^{\circ}$ & $45.31^{\circ}(\mathrm{Jan})$ & $14.66^{\circ}$ (Jun) \\
\hline & ERA-Interim & $43.77^{\circ} \mathrm{N}$ & Aug & $25.89^{\circ} \mathrm{N}$ & May & $17.88^{\circ}$ & $49.23^{\circ}(\mathrm{Feb})$ & $15.11^{\circ}$ (Jun) \\
\hline & CFSR & $42.72^{\circ} \mathrm{N}$ & Sep & $24.51^{\circ} \mathrm{N}$ & May & $18.21^{\circ}$ & $49.59^{\circ}(\mathrm{Feb})$ & $9.12^{\circ}($ Jun $)$ \\
\hline \multirow{6}{*}{ Equator-ward } & NCEP/NCAR & $19.34^{\circ} \mathrm{N}$ & Aug & $14.90^{\circ} \mathrm{S}$ & Jan & $34.24^{\circ}$ & \multicolumn{2}{|c|}{1} \\
\hline & NCEP-DOE & $18.09^{\circ} \mathrm{N}$ & Aug & $15.67^{\circ} \mathrm{S}$ & Jan & $33.76^{\circ}$ & \multicolumn{2}{|c|}{ i } \\
\hline & ERA40 & $18.75^{\circ} \mathrm{N}$ & Aug & $13.56^{\circ} \mathrm{S}$ & Jan & $32.31^{\circ}$ & \multirow{2}{*}{\multicolumn{2}{|c|}{1}} \\
\hline & JRA25 & $19.27^{\circ} \mathrm{N}$ & Aug & $14.33^{\circ} \mathrm{S}$ & Jan & $33.60^{\circ}$ & & \\
\hline & ERA-Interim & $19.25^{\circ} \mathrm{N}$ & Aug & $11.76^{\circ} \mathrm{S}$ & Feb & $31.01^{\circ}$ & & \\
\hline & CFSR & $19.73^{\circ} \mathrm{N}$ & Aug & $14.77^{\circ} \mathrm{S}$ & Jan & $34.50^{\circ}$ & & \\
\hline
\end{tabular}

comparison and a clear sight, the detailed information regarding the edges and width of $\mathrm{HC}$ is listed in Table 1 . We see that the amplitude of pole-ward edge in the $\mathrm{NH}$ is larger than that in the $\mathrm{SH}$, accordingly the width of $\mathrm{HC}$ in the $\mathrm{NH}$ shows a larger amplitude than that in the SH during the seasonal march. And the amplitude of the equator-ward edge of $\mathrm{HC}$ is much more extensive than those of the pole-ward edges in both hemispheres.

\section{Conclusions and discussion}

Using six different reanalysis datasets, we have examined the climatological seasonal march characteristics of the tropical $\mathrm{HC}$, including both the locations of its pole-ward, equator-ward edges, and the width. The consistent result emerged from our analyses suggests the following conclusion: (1) both the poleward and equator-ward edges of $\mathrm{HC}$ show strong seasonal shift. This is consistent with the result as reported in Dima and Wallace (2003). And the amplitude of equator-ward edge of $\mathrm{HC}$ is much larger than that of the pole-ward edges in both hemispheres; (2) The width of $\mathrm{HC}$ in the $\mathrm{SH}$ is within $20^{\circ} \sim 50^{\circ}$ latitudes within the seasonal march. Meanwhile, it is $11^{\circ} \sim 48^{\circ}$ latitudes for the $\mathrm{NH}$. This implies the seasonal variation of $\mathrm{HC}$ is much intense in the $\mathrm{NH}$ than that in the SH. Of note is that the pole-ward edge of $\mathrm{HC}$ in the NH reaches its southernmost location in May, and northernmost location in August, showing a very rapid northward jump, after then the pole-ward edge moves southwardly, which is quite different from that in the SH. Note that May is right paralleling to the timing when the Asian summer monsoon would onset, and August is corresponding to the mature phase of the Asia summer monsoon. To this point, what is the possible reason for the abrupt northward shift of the $\mathrm{HC}$, and to what degree does it been influenced by the large scale Asian summer monsoon system, and what is the possible physical procession involved? These are still open questions.

Nevertheless, the analysis reveals that both the width and edges of the tropical $\mathrm{HC}$ undergo strong seasonal variations. And the result raises that the reanalysis datasets from ERA40, CFSR (for the pole-ward edge of $\mathrm{HC}$ in the $\mathrm{SH}$ ) and JRA25 (for the pole-ward edge of $\mathrm{HC}$ in the $\mathrm{NH}$ ) show big discrepancy comparing with the other datasets in depicting the locations of pole-ward edges of $\mathrm{HC}$. Considering that the $\mathrm{HC}$ is mainly a thermal-driven circulation, and the seasonal shift of $\mathrm{HC}$ is mainly associated with the seasonal shift of the sun, indicating the result from them is less reasonable regarding the seasonal variations. Thus the NCEP/ NCAR and NCEP-DOE are recommended in analyzing the seasonal characteristics of $\mathrm{HC}$. Besides, we found there is large vertical structure of the $\mathrm{HC}$ edges, particular for the pole-ward edge in the $\mathrm{NH}$, thus the result based on the middle and upper troposphere would be more suitable when the locations of $\mathrm{HC}$ is investigated.

In addition, we have examined the other data to further illustrate the seasonal march of the $\mathrm{HC}$, as well as its edges and locations. For example, we examined the rainfall distribution due to the fact that the ascending branch of $\mathrm{HC}$ is associated with the maximum locations of the rainfall in physic within the tropics. However, it is seen that the maximum position of zonal mean rainfall shows a continuous northward shift from January to August, and nearly being stable from August to December (figures not shown). This feature is not consistent with the seasonal march of the HC. As to the descending branch of the $\mathrm{HC}$, due to the complexity of the terrain and circulations in the extra-tropics, the maximum locations of rainfall and convection are not paralleling to the positions of descending branch either. Therefore, we did not include the result based on rainfall and convection in this study due to the limitation. We would like to further discussion this issue by employing the CMIP5 simulations.

One thing noted is that although the pole-ward expansion of $\mathrm{HC}$ had been intensely reported, the equator-ward edge of $\mathrm{HC}$ has not been intensely considered in previous studies; the result in this study indicates the seasonal variation of the equator-ward edge of $\mathrm{HC}$ is much bigger than those in the pole-ward edges. To this point, what about the long term variations of the $\mathrm{HC}$ equator-ward edge in each season, showing some trends or not? Finally, in view of the importance of the $\mathrm{HC}$, its vertical structure provides a criterion against which the output of general circulation models (GCMs) can be assessed, and that its sensitivity to climate change forcing can be assessed. This appears to provide a useful "fingerprinting" technique for this particular aspect of climate change.

\section{Acknowledgements}

This work was jointly supported by the National Natural Science Foundation of China (41475076, 41290255, and 41205046).

Edited by: H. Kamahori 


\section{References}

Chen, J. Y., B. E. Carlson, and A. D. Genio, 2002: Evidence for strengthening of the tropical general circulation in the 1990s. Science, 295, 838-841.

Dee, D. P., S. M. Uppala, A. J. Simmons, and co-authors, 2011: The ERA-Interim reanalysis: Configuration and performance of the data assimilation system. Quart. J. Roy. Meteor. Soc., 137, 553-597.

Diaz, H. F., and B. Bradley, 2004: The Hadley Circulation: Present, Past and Future. Kluwer Academic Publishers, The Netherlands.

Dima, I. M., and J. M. Wallace, 2003: On the seasonality of the Hadley Cell. J. Atmos. Sci., 60, 1522-1526.

Feng, J., J. P. Li, and F. Xie, 2013: Long-term variation of the principal mode of boreal spring Hadley circulation linked to SST over the Indo-Pacific warm pool. J. Climate, 26, 532544.

Feng, J., and J. P. Li, 2013: Contrasting impacts of two types of ENSO on the boreal spring Hadley circulation. J. Climate, 26, 4773-4789.

Feng, J., J. P. Li, J. L. Zhu, and co-authors, 2015: Simulation of the equatorially asymmetric mode of the Hadley circulation in CMIP5 models. Adv. Atmos. Sci., 32, 1129-1142, doi: 10.1007/s00376-015-4157-0.

Feng, R., J. P. Li, and J. C. Wang, 2011: Regime change of the boreal summer Hadley circulation and its connection with the tropical SST. J. Climate, 24, 3867-3877.

Fu, Q., C. M. Johanson, J. M. Wallace, and T. Reichler, 2006: Enhanced mid-latitude tropospheric warming in satellite measurements. Science, 312, 1179 .

Guo, Y. P., J. P. Li, J. Feng, and co-authors, 2016: The multidecadal variability of the asymmetric mode of the boreal autumn Hadley circulation and its link to the Atlantic Multidecadal Oscillation. J. Climate, accepted.

Held, I. M., and A. Y. Hou, 1980: Nonlinear axially symmetric circulations in a nearly inviscid atmosphere. J. Atmos. Sci., 37, 515-533.

Hou, A. Y., 1998: Hadley circulation as a modulator of the extratropical climate. J. Climate, 55, 2437-2457.

$\mathrm{Hu}$, Y. Y., and Q. Fu, 2007: Observed poleward expansion of the Hadley circulation since 1979. Atmos. Chem. Phys., 7, 5229-5236.

Hu, Y. Y., and C. Zhou, 2009: Decadal changes in the Hadley circulation. Advances in Geosciences, J. H. Oh, Ed., World Scientific Publishing Company, Singapore, 250pp.

Hu, Y. Y., K. K. Tung, and J. Liu, 2005: A closer comparison of early and late winter atmospheric trends in the Northern Hemisphere. J. Climate, 18, 2924-2936.

$\mathrm{Hu}$, Y. Y., L. J. Tao, and J. P. Liu, 2013: Poleward expansion of the Hadley circulation in CMIP5 simulations. Adv. Atmos. Sci., 30, 790-795.

Hudson, R. D., M. F. Andrade, M. B. Follette, and co-authors, 2006: The total zone field separated into meteorological regimes-Part II: Northern Hemisphere mid-latitude total ozone trends. Atmos. Chem. Phys., 6, 5183-5191.

Johanson, C., and Q. Fu, 2009: Hadley cell widening: model simulations versus observations. J. Climate, 22, 2713-2725.

Kalnay, E., and co-authors, 1996: The NCEP/NCAR 40-Year Reanalysis Project. Bull. Amer. Meteor. Soc., 77, 437-472.

Kanamitsu, M., W. Ebisuzaki, J. Woollen, and co-authors, 2002: NCEP-DOE AMIP-II Reanalysis (R-2). Bull. Amer. Meteor. Soc., 83, 1631-1643.

Kobayashi, C., and S. Maeda, 2006: Phase shift of the seasonal cycle in the Hadley circulation in recent decades. Geophys. Res. Lett., 33, L22703, doi:10.1029/2006GL027682.

Li, J. P., 2001: Climatological mean state. Atlas of Climate of
Global Atmospheric Circulation (in Chinese), Beijing, China Meteorological Press, 279pp.

Lindzen, R. S., 1994: Climate dynamics and global change. Annu. Rev. Fluid Mech., 26, 353-378.

Lu, J., G. A. Vecchi, and T. Reichler, 2007: Expansion of the Hadley cell under global warming. Geophys. Res. Lett., 34, L06805, doi:10.1029/2006GL028443.

Karnauskas, K. B., and C. C. Ummenhofer, 2014: On the dynamics of the Hadley circulation and subtropical drying. Climate Dyn., 42, 2259-2269.

Ma, J., and J. P. Li, 2007: The reason for the strengthening of the boreal winter Hadley circulation and its connection with ENSO. Prog. Nat. Sci., 17, 1327-1333.

Ma, J., and J. P. Li, 2008: The principal modes of variability of the boreal winter Hadley cell. Geophys. Res. Lett., 35, L01808, doi:10.1029/2007GL031883.

Mitas, C. M., and A. Clement, 2005: Has the Hadley cell been strengthening in recent 329 decades? Goephys. Res. Lett., 32, L03809, doi:10.1029/2004GL021765.

Mitas, C. M., and A. Clement, 2006: Recent behavior of the Hadley cell and tropical thermodynamics in climate models and reanalyses. Geophys. Res. Lett., 33, L01810, doi:10.1029/ 2005 GL024406.

Onogi, K., H. Koide, M. Sakamoti, and co-authors, 2005: JRA25: Japanese 25-year re-analysis project-Progress and status. Quart. J. Roy. Meteor. Soc., 131, 3259-3268.

Oort, A. H., and J. J. Yienger, 1996: Observed interannual variability in the Hadley circulation and its connection to ENSO. J. Climate, 9, 2751-2767.

Pawson, S., and M. Fiorino, 1998: A comparison of reanalyses in the tropical stratosphere: Part 1. Thermal structure and the annual cycle. Climate Dyn., 14, 631-644.

Qin, Y. J., and P. X. Wang, 2015: Anomalies of the ascending branch structure in the Hadley cell over the eastern Asia monsoon region and their impacts on the precipitation in the Yangtze river basin in summer. J. Tropical Meteor., 31, 467474.

Quan, X. W., H. F. Diaz, and M. P. Hoerling, 2004: Change in the tropical Hadley cell since 1950. Hadley Circulation: Present, Past and Future, H. F. Diaz, and R. S. Bradley, Eds., Springer, 85-120.

Saha, S., S. Moorthi, H. L. Pan, and co-authors, 2010: The NCEP climate forecast system reanalysis. Bull. Amer. Meteor. Soc., 91, 1015-1057.

Seidel, D. J., and R. J. Randel, 2007: Recent widening of the tropical belt: evidence from tropopause observations. J. Geophys. Res., 112, D20113, doi:10.1029/2007JD008861.

Tanaka, H. L., N. Ishizaki, and A. Kitoh, 2004: Trend and interannual variability of Walker, monsoon and Hadley circulations defined by velocity potential in the upper troposphere. Tellus $A$, 56, 250-269.

Uppala, S., and co-authors, 2005: The ERA-40 reanalysis. Quart. J. Roy. Meteor. Soc., 612, 2961-3012.

Wielicki, B. A., T. Wong, R. P. Allan, and co-authors, 2002: Evidence for large decadal variability in the tropical mean radiative energy budget. Science, 295, 841-843.

Zhao, Y. F., and J. P. Li, 2006: Discrepancy of mass transport between the Northern and the Southern Hemisphere among the ERA-40, NCEP/NCAR, NCEP-DOE AMIP-2 and JRA25 Reanalysis. Geophys. Res. Lett., 33, L20804, doi:10.1029/ 2006 GL027287.

Zhou, B. T., and H. J. Wang, 2006: Interannual and interdecadal variations of the Hadley circulation and its connection with tropical sea surface temperature. Chinese J. Geophys., 49, 1271-1278 (in Chinese).

Manuscript received 29 March 2016, accepted 11 July 2016

SOLA: https://www.jstage.jst.go.jp/browse/solal 